\title{
Health Promotion Model on Preventive Behaviors of Risk Factors for Adults' Metabolic Syndrome in Ponorogo, Indonesia
}

\author{
Edy Bachrun ${ }^{1}$, Bhisma Murti², Mahendra Wijaya ${ }^{3} \&$ Endang Sutisna Sulaeman ${ }^{4}$ \\ ${ }^{1}$ Doctoral Program of Health Promotion and Community Development, Universitas Sebelas Maret, Surakarta, \\ Indonesia \\ ${ }^{2}$ Masters Program in Public Health, Universitas Sebelas Maret, Surakarta, Indonesia \\ ${ }^{3}$ Faculty of Social and Political Science, Universitas Sebelas Maret, Surakarta, Indonesia \\ ${ }^{4}$ Public Health Science, Faculty of Medicine, Universitas Sebelas Maret, Surakarta, Indonesia \\ Correspondence: Edy Bachrun, Master Program, Sebelas Maret University, Ir Sutami Street no. 36A Surakarta, \\ Central Java, Indonesia.
}

Received: December 29, 2020 Accepted: March 8, 2021 Online Published: March 17, 2021

doi:10.5539/gjhs.v13n4p132 URL: https://doi.org/10.5539/gjhs.v13n4p132

\begin{abstract}
In Ponorogo, there are three risk factors for metabolic syndrome higher than national numbers that are $74 \%$ of physical inactivity with $26.1 \%$ of national number, $46.9 \%$ of hypertension risk with $26.6 \%$ of national number, and $40.6 \%$ of weight with $28.9 \%$ of national number (Rosjidi et al., 2015). This research aimed at finding out the effects of individual beliefs, social capital and other effects on preventive behaviors of risk factors for adults' metabolic syndrome. This control case study was employed on October 2019 in Ponorogo Regency, East Java, Indonesia. The dependent variables were preventive behaviors of risk factors for metabolic syndrome. The independent variables were perceived susceptibility, perceived severity, perceived benefits, perceived barriers, self-efficacy, governmental support, peer support, social capital, imitation, collective efficacy, and outcome expectations. The data was obtained using questionnaires and then analyzed by using a path analysis of 13 strata program. There were direct effects of self-efficacy, perceived benefits, perceived barriers, and perceived severity on preventive behaviors of risk factors for metabolic syndrome. There were indirect effects of perceived susceptibility toward perceived severity, perceived benefits toward perceived barriers, governmental support toward perceived barriers, peer support toward imitation, collective efficacy toward self-efficacy, imitation toward self-efficacy, outcome expectations toward perceived benefits, social capital toward collective efficacy, imitation through toward preventive behaviors of risk factors for metabolic syndrome.
\end{abstract}

Keywords: promotion, prevention, metabolic syndrome

\section{Introduction}

According to Shahab (2017), metabolic syndrome is a clinical condition where a person has symptoms of metabolic disorders, including dyslipidemia (increased triglyceride levels, decreased HDL cholesterol levels), insulin resistance, high blood pressure (hypertension), and high blood sugar (obesity). This syndrome is a group of metabolic abnormalities triggered by changes in lifestyle such as a low physical activity which is relaxed and lazy, high-carbohydrate diets and low fibers, which cause obesity (waist circumference $\geq 88 \mathrm{~cm}$ in women and $\geq 102 \mathrm{~cm}$ in men).

The main risk factors for metabolic syndrome are obesity and an inactive lifestyle. This condition also causes the insulin resistance in some people. The data of the basic health research of Indonesian Ministry of Health in 2013 showed an increase in the prevalence of national central obesity, from $18.8 \%$ (2007) to 26.6\% (2013), then increased to 31.0\% (2018) (Indonesian Basic Health Research, 2018). On the other hand, the prevalence of obesity in East Java decreased from 27.3\% to 18.8\% (Indonesian Basic Health Research, 2018), then increased 30.38\% (2018) (Indonesian Basic Health Research, 2018). The vital finding of Rosyidi's research in 2015 conducted in Ponorogo Regency showed three risk factors for metabolic syndrome that were higher than national numbers, that was $74 \%$ of physical inactivity with $26.1 \%$ of national number, $46.9 \%$ of risk of hypertension with $26.6 \%$ of national number and $40.6 \%$ of overweight with national number of $28.9 \%$ (Rosjidi et al., 2015). Based on various risk factors, it can be analyzed that metabolic syndrome is mostly caused by an unhealthy lifestyle or behaviors. 
The health campaigns have already been developed by the government to reduce the number of patients with metabolic syndrome through Integrated Training Posts (ITPs) by monitoring weight gain with the measurement of wrist size and blood pressure, encouraging a physical activity, encouraging to stop-smoking and eating healthy nutritious diets.

These efforts seem unable to reduce the prevalence of metabolic syndrome. The most suitable strategy of health campaigns to change the behaviors is by empowering the community at the micro, meso, exo and macro levels. Dahlgren and Whitehead (1991 in Murti, 2016) in the eco-social theory of health explained that the health/disease experienced by individuals is influenced by various environment factors, most of which are determinants of the health can actually be changed (modifiable factors). Based on this model of socioeconomic determinants of health, the optimal health of individuals, groups, and communities requires the realization of the full potential of the individual, physically, psychologically, socially, spiritually, and economically, fulfilling the expectations of one's role in the family, community, workplace, and the realization of macro policies that can improve macro environmental conditions (Dahlgren \& Whitehead, 1991; Murti, 2016).

Based on those problems, it is needed to conduct a research about factors affecting preventing behaviors of the risk factors for metabolic syndrome in Ponorogo using the Health Belief Model from Redenstock, Precede-Proceed planning theory from Lawrens Green and Social Cognitive Theory from Bandura.

\section{Research Method}

\subsection{Type of Research}

This type of research is quantitative, analyzing the relationship between one variable and another (Murti, 2016). The research location was conducted in Ponorogo Regency, East Java, Indonesia in October 2019.

\subsection{Population and Sample}

The target population was 300 adults at the age of 26-45 recorded in the health service register book in Ponorogo, with the distribution of 100 cases and 200 controls. The sample was selected based on fixed disease sampling. This research analyzed 11 variables, so that the sample must be at least 220 (11 variables $\mathrm{x} 20$ subjects) rounded to 300 subjects.

\subsection{Research Variables}

The dependent variable was preventive behaviors of risk factors for metabolic syndrome (lack of exercises, smoking habits, unhealthy diets). The independent variable included perceived susceptibility, perceived severity, perceived benefits, perceived barriers, self-efficacy, governmental support, peer support, social capital, imitation, collective efficacy, and outcome expectations.

\section{Result}

The result of Path Analysis

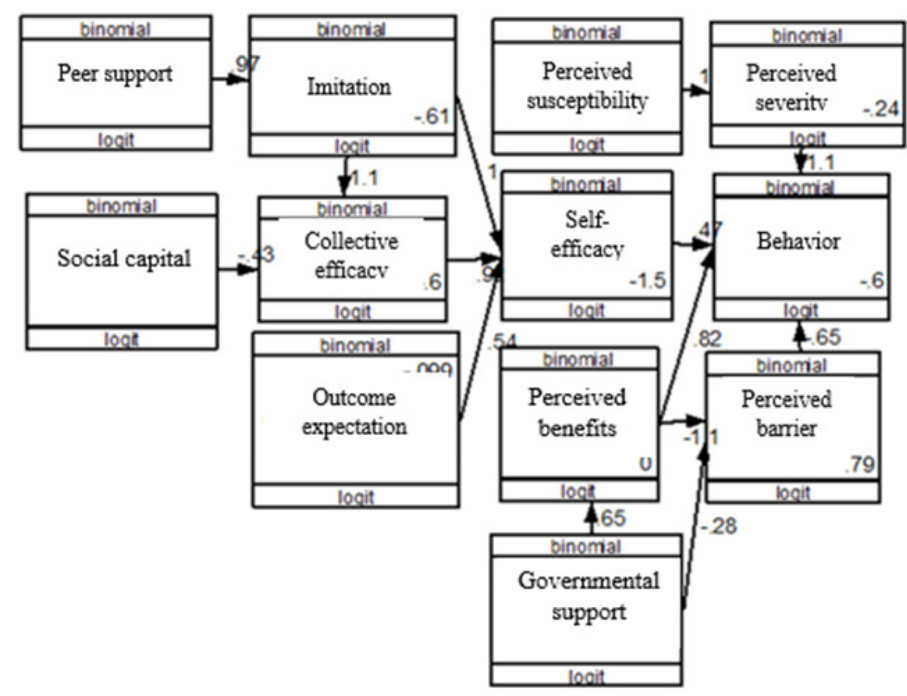

Figure 1. The Model of Path Analysis on Predicator for Preventive Behaviors of Risk Factors for Metabolic Syndrome 
Table 2. The Result of Path Analysis on Determinants for Preventive Behaviors of Risk Factors for Metabolic Syndrome

\begin{tabular}{|c|c|c|c|c|}
\hline \multirow{2}{*}{ Variable } & \multirow{2}{*}{ Path Coefficient (b) } & \multicolumn{2}{|c|}{ Coefficient Interval/CI (95\%) } & \multirow{2}{*}{$\mathbf{p}$} \\
\hline & & Lower Boundary & Upper Boundary & \\
\hline \multicolumn{5}{|l|}{ Direct } \\
\hline \multicolumn{5}{|l|}{ Preventive Behaviors } \\
\hline Self-Efficacy (high) & 0.47 & -0.06 & 1.01 & 0.087 \\
\hline Benefits (high) & 0.82 & 0.28 & 1.36 & 0.003 \\
\hline Barriers (low) & -0.64 & -1.17 & -0.11 & 0.016 \\
\hline Severity (high) & 1.07 & 0.54 & 1.19 & $<0.001$ \\
\hline \multicolumn{5}{|l|}{ Indirect } \\
\hline \multicolumn{5}{|l|}{ Susceptibility } \\
\hline Susceptibility (high) & 1.02 & 0.54 & 1.49 & $<0.001$ \\
\hline Benefits (high) & -1.11 & -1.59 & -0.62 & $<0.001$ \\
\hline Governmental Support (high) & -0.27 & -0.75 & 0.20 & 0.255 \\
\hline \multicolumn{5}{|l|}{ Imitation } \\
\hline Peer Support (high) & 0.96 & 0.46 & 1.47 & $<0.001$ \\
\hline \multicolumn{5}{|l|}{ Self-Efficacy } \\
\hline Collective Efficacy (high) & 0.91 & 0.41 & 1.41 & $<0.001$ \\
\hline Imitation (available) & 1.04 & 0.53 & 1.54 & $<0.001$ \\
\hline Outcome expectation (positive) & 0.53 & 0.03 & 1.03 & 0.035 \\
\hline \multicolumn{5}{|l|}{ Benefits } \\
\hline Governmental Support (high) & 0.64 & 0.18 & 1.11 & 0.007 \\
\hline \multicolumn{5}{|l|}{ Collective Efficacy } \\
\hline Social capital (high) & -0.42 & -0.90 & 0.05 & 0.084 \\
\hline Imitation & 0.96 & 0.46 & 1.47 & $<0.001$ \\
\hline
\end{tabular}

Self-Efficacy had a direct and positive effect toward the preventive behavior of risk factors for metabolic syndrome. Adults with a high self-efficacy had log-odds for preventive behaviors of risk factors for metabolic syndrome by 0.47 unit higher $(b=0.47 ; C I 95 \%=-0.06$ to $101 ; \mathrm{p}=0.087)$, than adults with a low self-efficacy. The perceived benefits of preventive disease affected directly and positively toward the preventive behaviors of risk factors for metabolic syndrome. Adults with a high perceived benefits preventive disease had logged for preventive behavior of risk factors for metabolic syndrome by 0.82 unit higher $(\mathrm{b}=0.82$; $\mathrm{CI} 95 \%=0.28$ to 1.36 ; $\mathrm{p}=$ 0.003 .) than adults with a low belief. The perceived barriers affected directly and negatively toward the preventive behaviors of risk factors for metabolic syndrome. Adults with low perceived barriers had log-odds for preventive behaviors of risk factors for metabolic syndrome by -.64 unit higher $(b=-0.64 ; C I 95 \%=-1.17$ to $-0.11 ; p=0.016)$ than adults with high perceived barriers. The perceived severity affected directly and positively toward preventive behaviors of risk factors for metabolic syndrome. Adults with a high perceived severity had log-odds for preventive behaviors of risk factors for metabolic syndrome by 1.07 unit higher $(b=1.07 ; \mathrm{CI} 95 \%=0.54$ to $1.60 ; \mathrm{p}<$ 0.001 ) than adults with a low perceived severity.

The perceived susceptibility affected indirectly and negatively toward preventive behaviors of risk factors of metabolic syndrome through the perceived severity. Adults with a high perceived susceptibility and a high perceived severity had log-odds for preventive behaviors of risk factors for metabolic syndrome by 1.02 unit higher $(b=1.02$; CI $95 \%=0.54$ to $1.49 ; p<0.001)$ than adults with a low perceived susceptibility. The perceived benefits affected indirectly and negatively toward preventive behaviors of risk factors for metabolic syndrome through perceived barriers. Adults with high preventive benefits and low perceived barriers had log-odds for preventing risk factors for metabolic syndrome by -1.11 unit higher $(b=-1.11$; CI $95 \%=-1.59$ to $-0.62 ; \mathrm{p}<0.001)$ 
than adults with low perceived benefits. The governmental supports affected indirectly and negatively toward preventive behaviors of risk factors for metabolic syndrome through perceived barriers. Adults with a high governmental support and low perceived barriers had log-odds for preventing risk factors for metabolic syndrome by -0.24 unit higher $(b=-0.24 ; C I 95 \%=-0.75$ to $0.20 ; p=0.255$ ) than adults with a low governmental support.

The peer support affected indirectly and positively toward preventing behaviors of risk factors for metabolic syndrome through imitation. Adult with a high peer support and having imitation had log-odds for preventive behaviors of risk factors for metabolic syndrome by 0.96 unit higher $(b=0.96 ; C I 95 \%=0.41$ to $1.47 ; p<0.001)$ than adults without a peer support.

Collective efficacy affected indirectly and positively toward preventive behaviors of risk factors for metabolic syndrome through self-efficacy. Adults with a high collective efficacy and a high self-efficacy had log-odds for preventive behaviors of risk factors for metabolic syndrome by 0.91 unit higher $(b=0.91 ; \mathrm{CI} 95 \%=0.41$ to $1.41 ; \mathrm{p}<$ 0.001 ) than adults with a low collective efficacy. Imitation affected indirectly and positively toward preventive behaviors of risk factors for metabolic syndrome through self-efficacy. Adults with a high imitation and a high self-efficacy had log-odds for preventive behaviors of risk factors for metabolic syndrome by 1.04 unit higher $(b=$ 1.04; CI $95 \%=0.53$ to $1.54 ; \mathrm{p}<0.001)$ than adults without imitation. The expected results had an indirect and positive effect on the preventive behavior of risk factors for metabolic syndrome through self-efficacy. Adults with high positive outcome expectations and self-efficacy had log-odds for preventive behaviors of risk factors for metabolic syndrome by 0.53 units higher $(b=0.53 ; 95 \% \mathrm{CI}=0.03$ to $1.03 ; \mathrm{p}=0.035)$ than adults with negative outcome expectations.

The governmental support affected indirectly and positively toward preventive behaviors of risk factors for metabolic syndrome through perceived benefits. Adults with a high governmental support and high perceived benefits had log-odds for preventive behaviors of risk factors for metabolic syndrome by 0.64 unit higher $(b=0.64$; CI $95 \%=0.18$ to $1.11 ; \mathrm{p}=0.007$ ) than adults with a low governmental support.

The social capital affected indirectly and negatively toward preventive behaviors of risk factors for metabolic syndrome through a collective efficacy. Adults with a high social capital and a high collective efficacy had log-odds for preventive behaviors of risk factors for metabolic syndrome by -0.42 unit higher $(b=-0.42$; CI $95 \%=$ -0.90 to $0.05 ; \mathrm{p}=0.084$ ) than adults with a low social capital. Imitation affected indirectly toward preventive behaviors of risk factors for metabolic syndrome through a collective efficacy. Adults with an imitated role model had log-odds for preventive behaviors of risk factors for metabolic syndrome by 1.11 unit higher $(b=1.11$; CI $95 \%=0.64$ to $1.59 ; \mathrm{p}<0.001)$ than adults without an imitation.

\section{Discussion}

\section{a. Preventive Behaviors of Risk Factors for Metabolic Syndrome and Self-Efficacy}

The findings show that self-efficacy is a predictor for an individual for preventive behaviors of risk factors for metabolic syndrome. An individual with a strong self-efficacy has an ability to complete difficult tasks as a challenge that has to be conquered and does not have to be avoided. In the Social Cognitive Theory, self-efficacy is believed as a factor to determine how people feel, think, and motivate themselves to behave (Bandura, 1994).

\section{b. Preventive Behaviors of Risk Factors for Metabolic Syndrome and Perceived Preventive Benefits}

The findings show that perceived benefits of preventive disease is a predictor affecting an individual for preventing risk factors for metabolic syndrome. The previous research done by Brzoska et al. (2018) in West Virginia shows that the construction of perceived benefits and perceived barriers has a significant correlation toward the preventive management of diabetes mellitus $(r=0,29, p=0,015 \& r=0,366, p=0,002$, respectively) showing that an individual with a good condition gets greater benefits of the program and lower barriers of the participations.

\section{c. Preventive Behaviors of Risk Factors for Metabolic Syndrome and Perceived Barriers}

The findings show that the perceived barriers a predictor affecting toward an individual for preventing risk factors for metabolic syndrome. This research is in line with the research done by Shabibi et al. (2014) that there is a significant effect between the perceived barriers and the improvement of self-care behaviors of patients of type II Diabetes Mellitus in Ilam Iran. Moreover, Lo et al. (2015) in their research also state that the perceived barriers is a predicator affecting individual behaviors to exercises for preventing risk factors for metabolic syndrome in Hong Kong.

\section{d. Preventive Behaviors of Risk Factors for Metabolic Syndrome and Perceived Severity}

The findings show that the perceived severity is an individual predicator for preventing risk factors for metabolic syndrome. The more individuals believe that they have a more-serious disease, they will feel that as a threat and 
then take preventive behaviors of risk factors for metabolic syndrome. This research is in line with the research done by Fitriani et al. (2019). The analysis result of multiple logistic regression shows the perceived threats affects the obedience of the patients of type II Diabetes Mellitus in the insulin use.

\section{e. Preventive Behaviors of Risk Factors for Metabolic Syndrome and Perceived Susceptibility}

The path analysis in this study supports the hypothesis that a high perceived susceptibility affects individuals for preventing risk factors for metabolic syndrome through the indirect believed severity. This study is in line with the research done by Aramwiroj et al. (2014) in Thailand explaining that perceived susceptibility has a positive and significant effect on preventive behaviors of osteoporosis, while perceived severity has a low positive effect on preventing osteoporosis $(r=0.633$ and $0.366 ; p=0.05)$. In addition, it is found that the perceived susceptibility and the perceived severity variable have a significant linear correlation that is able to predict the preventive behaviors of participants.

\section{f. Preventing Behaviors of Risk Factors for Metabolic Syndrome and Perceived Benefits}

The results of the path analysis indicate that there is an indirect and negative effect between perceived benefits toward preventive behaviors of risk factors for metabolic syndrome through perceived severity. Perceived benefit refers to an individual's assessment of the value or efficacy of engaging in health-promoting behaviors to reduce disease risk (Janz et al., 1984). Meanwhile, perceived severity refers to a subjective assessment of the consequence level of potential health problems (Glanz et al., 2002).

\section{g. Preventive Behaviors of Risk Factors for Metabolic Syndrome and Governmental Support}

The findings show that there is an effect of the governmental support toward preventing behaviors of risk factors for metabolic syndrome through perceived severity. The governmental support is in the form of assistance, giving attention, giving encouragement, providing information, suggestions, and directions given by health workers to individuals, families and communities to change unhealthy behaviors. Governmental support is also manifested by the ministry of health regulation number 28 of 2013 concerning on the inclusion of warnings and health information on packaging and the ministry of health regulation number 30 of 2013 which is then changed to the ministry of health regulation number 63 of 2015 article 4 paragraph 2 saying "Sugar consumption is more than 50 grams, sodium is more than 2000 milligrams or total fat of more than 67 grams/day/person is at risk of causing hypertension, stroke, diabetes mellitus, and heart attack."

\section{h. Preventive Behaviors of Risk Factors for Metabolic Syndrome and Peer Support}

Adults with a strong peer support have a 0.96 unit higher probability of preventive behaviors of risk factors for metabolic syndrome. The results of this study are in line with the research done by Tantri, (2018) that there is an effect of a peer support on the self-care behavior of type II Diabetes Mellitus patients. This research is also in accordance with the results of research done by Songthai et al. (2014). The findings show that a peer support influences on self-management program to reduce adults' blood pressure in Thailand.

\section{i. Preventive Behaviors of Risk Factors for Metabolic Syndrome and Collective Efficacy}

Adults with a strong collective efficacy have log-odds for preventive behaviors of risk factors for metabolic syndrome by 0.91 unit higher than adults a lower collective efficacy. Collective efficacy is the willingness of community members to care for each other and intervene when problems arise (Kohen et al., 2006). Adult communities in Ponorogo are able to solve the level difficulty for preventing behaviors of risk factors for metabolic syndrome in order to become the together movement in groups for preventing behaviors of risk factors for metabolic syndrome.

j. Imitation Effects on Preventive Behaviors of Risk Factors for Metabolic Syndrome through Self-Efficacy Variable

Adults in Ponorogo district with a strong self-imitation and efficacy have log-odds for preventive behaviors of risk factors for metabolic syndrome by 1.04 units higher $(b=1.04 ; 95 \% \mathrm{CI}=0.53$ to $1.54 ; \mathrm{p}=0 .<001)$ than adults without imitation. After seeing the success of other people in preventing risk factors for metabolic syndrome and feeling confident that they can perform such behavior, adults in Ponorogo district are motivated to carry out preventive behaviors of risk factors for metabolic syndrome risk factors. The results of this study prove that individuals learn to imitate or imitate the behavior of others who become a model for themselves after they have the confidence to be able to do so.

\section{Conclusions}

There are direct and indirect influences between perceived susceptibility, perceived seriousility, perceived benefits, 
perceived barriers, self-efficacy, governmental support, peer support, social capital, collective efficacy, outcome expectations and imitation for preventive behaviors of risk factors for adult's metabolic syndrome in Ponorogo.

\section{Competing Interests Statement}

The authors declare that there are no competing or potential conflicts of interest.

\section{References}

Aramwiroj, M., Chaikoolvatana, A., \& Chaikoolvatana, C. (2014). The relations between perceived susceptibility, perceived severity, and preventive behavior to osteoporosis of high-risk persons in five provinces in North-Eastern Thailand. Retrieved from https://www. researchgate.net/publication/266920747

Cohen, D., Finch, B., Bower, A., \& Sastry, N. (2006). Collective efficacy and obesity: the potential influence of social factors on health. Social science \& medicine, 62(3), 769-78. https://doi.org/10.1016/j.socscimed.2005.06.033

Dahlgren, G., \& Whitehead, M. (2006). European Strategies for Tackling Social Inequities in Health: Levelling up Part 2. World Health Organization Regional Office for Europe. Retrieved from https://apps.who.int/iris/handle/10665/107791

Fitriani, Y., Pristianty, L., \& Hermansyah, A. (2019). Pendekatan Health Belief Model (HBM) untuk Menganalisis Kepatuhan Pasien Diabetes Melitus Tipe 2 dalam Menggunakan Insulin. Pharmaceutical Journal of Indonesia, 16(2) 167-177. https://doi.org/10.30595/pharmacy.v16i2.5427

Glanz, K., Rimer, B. K., \& Viswanath, K. (Ed). (2008). Health Behavior and Health Education: Theory, Research, and Practice (4th ed.). jossey-bass. Retrieved from https://psycnet.apa.org/ record/ 2008-17146-000

Janz, N., \& Becker, M. H. (1984). The Health Belief Model: A Decade Later. Health Education \& Behavior, 11, 147. https://doi.org/10.1177/109019818401100101

Lo, S.W., Chair, S.Y., \& Lee, F. K. (2015). Factors Associated with Health-Promoting Behavior of People with or at High Risk of Metabolic Syndrome: Based on the Health Belief Model. Applied Nursing Research: ANR, 28(2), 197-201. https://doi.org/10.1016/j.apnr.2014.11.001

Murti, B. (2010). Desain dan Ukuran Sampel untuk Penelitian Kuantitatif dan Kualitatif di Bidang Kesehatan. Gadjah Mada University Press. Yogyakarta.

Murti, B. (2016). Prinsip Dan Metode Riset Epidemiologi, Program Studi Ilmu Kesehatan Masyarakat Program Pascasarjana Universitas Sebelas Maret, Surakarta, Jawa Tengah.

Murti, B. (2018). Teori Promosi Dan Perilaku Kesehatan Edisi 1, Program Studi Ilmu Kesehatan Masyarakat, Program Pascasarjana, Universitas Sebelas Maret, Surakarta, Jawa Tengah.

Rosjidi, H. C., \& dan Isro'in, L. (2014). Kerentanan perempuan terhadap serangan penyakit jantung dan stroke. Retrieved from http://eprints.umpo.ac.id/id/eprint/1262

Shabibi, P., Zavareh, M., Sayehmiri, K., Qorbani, M., Safari, O., Rastegarimehr, B., \& Mansourian, M. (2017). Effect of educational intervention based on the Health Belief Model on promoting self-care behaviors of type-2 diabetes patients. Electronic physician, 9(12), 5960-5968. https://doi.org/10.19082/5960

Shawley-Brzoska, S., \& Misra, R. (2018). Perceived Benefits and Barriers of a Community-Based Diabetes Prevention and Management Program. J. Clin. Med., 7, 58. https://doi.org/10.3390/jcm7030058

Songthai, N., Subgranon, R., Kangchai, W., \& Rosenberg, E. (2014). Effects of Peer-support, Self-management Program on Self-management Behavior and Blood Pressure of Older Adults with Essential Hypertension. Chiang Mai University journal of natural sciences, 13. https://doi.org/10.12982/CMUJNS.2014.0042

Tantri, S. (2018). Pengaruh Peer Group Support Terhadap Perilaku Perawatan Diri Klien Diabetes Melitus Tipe 2 Di Wilayah Kerja Puskesmas Sumbersari Jember. Retrieved from https://repository.unej.ac.id/handle/123456789/86699

\section{Copyrights}

Copyright for this article is retained by the author(s), with first publication rights granted to the journal.

This is an open-access article distributed under the terms and conditions of the Creative Commons Attribution license (http://creativecommons.org/licenses/by/4.0/). 